\title{
Pengaruh Penganggaran Partisipatif terhadap Kinerja Manajerial dengan Persepsi Keadilan dan Komitmen Organisasi sebagai Variabel Mediasi dan Desentralisasi sebagai Variabel Moderasi pada Kementrian Agama Provinsi Sulawesi Utara
}

\author{
FELIX TONGIAN ${ }^{1}$, JULLIE J SONDAKH ${ }^{2}$, JENNY MORASA ${ }^{3}$ \\ 1,2,3 Program Magister Akuntansi, Fakultas Ekonomi dan Bisnis Universitas Sam Ratulangi \\ Email: felixtongian@gmail.com ${ }^{1}$, julliesondakh@yahoo.co.id ${ }^{2}$, jennymorasa@ymail.com ${ }^{3}$
}

\begin{abstract}
Good participatory budgeting will create a sense of justice that can make a person more committed and improve his performance. Reform in the field of state finance raises efforts to improve the public sector budgeting process with the implementation of performance-based budgeting. Participatory budgeting through fairness perceptions and organizational commitment is one of the factors for improving performance in the decentralized Ministry of Religious Affairs of North Sulawesi Province. The purpose of this research is to know the effect of participative budgeting on managerial performance either directly or indirectly by using perception of justice and organizational commitment as mediation variable as well as decentralization as moderation variable at Ministry of Religion of North Sulawesi Province. Instrument in this research is questionnaire with scale likert 1-5 and processed using program SPSS version 23. Analysis method used is Path Analysis to test indirect influence and residual test to test moderation variable. The results show that the perception of justice mediates the influence between participatory budgeting on managerial performance, and organizational commitment mediates the effect of participatory budgeting on managerial performance. While the decentralization variable does not moderate the influence between participative budgeting on managerial performance. This means that an increase in participatory budgeting will affect the improvement of managerial performance either directly or indirectly with the perception of justice and organizational commitment at the Ministry of Religious Affairs of North Sulawesi Province.
\end{abstract}

Keywords: Participatory Budgeting, Justice Perception, Organizational Commitment, Decentralization, Managerial Performance.

\begin{abstract}
Abstrak. Penganggaran partisipatif yang baik akan menimbulkan rasa keadilan sehingga dapat membuat seseorang lebih berkomitmen dan meningkatkan kinerjanya. Reformasi dibidang keuangan negara menimbulkan upaya memperbaiki proses penganggaran sektor publik dengan penerapan anggaran berbasis kinerja. Penganggaran partisipatif melalui persepsi keadilan dan komitmen organisasi menjadi salah satu faktor untuk peningkatan kinerja di Kementerian Agama Provinsi Sulawesi Utara yang terdesentralisasi. Tujuan penelitian ini untuk mengetahui pengaruh penganggaran partisipatif terhadap kinerja manajerial baik secara langsung maupun secara tidak langsung dengan menggunakan persepsi keadilan dan komitmen organisasi sebagai variabel mediasi serta desentralisasi sebagai variabel moderasi pada Kementerian Agama Provinsi Sulawesi Utara. Instrumen dalam penelitian ini adalah kuesioner dengan skala likert 1-5 dan diolah menggunakan program SPSS versi 23. Metode analisis yang digunakan adalah analisis jalur untuk menguji pengaruh tidak langsung dan uji residual untuk menguji variabel moderasi. Hasil penelitian menunjukan bahwa persepsi keadilan memediasi pengaruh antara penganggaran partisipatif terhadap kinerja manajerial dan komitmen organisasi memediasi pengaruh antara penganggaran partisipatif terhadap kinerja manajerial. Sedangkan variabel desentralisasi tidak memoderasi pengaruh antara penganggaran partisipatif terhadap kinerja manajerial. Artinya, peningkatan penganggaran partisipatif akan berpengaruh terhadap peningkatan kinerja manajerial baik secara langsung maupun secara tidak langsung dengan persepsi keadilan dan komitmen organisasi pada Kementerian Agama Provinsi Sulawesi Utara.
\end{abstract}

Kata kunci: Penganggaran Partisipatif, Persepsi Keadilan, Komitmen Organisasi, Desentralisasi, Kinerja Manajerial

\section{Pendahuluan}

Seiring dengan perkembangan paradigma baru dan gagasan dalam organisasi sektor publik yang terjadi di berbagai negara pada tahun 1980-an, munculah konsep yang disebut New Public Management (NPM). New Public Management memiliki fokus untuk mengadopsi keunggulan teknik manajemen perusahaan swasta yang kemudian diimplementasikan ke dalam sektor publik serta menekankan kontrol atas output kebijakan pemerintah yang berorientasi pada masyarakat. NPM muncul karena pemerintah dinilai terlalu kaku, birokratis dan tidak efisien sementara sektor swasta justru melakukan inovasi-inovasi baru dalam prinsip manajemennya untuk menemukan peluang dan bertahan dalam berkompetisi. New public management tidak hanya diterapkan di negara-negara 
dengan level kemakmuran tinggi seperti Inggris, Swedia, ataupun Selandia Baru, tetapi juga di negaranegara yang setara Indonesia seperti Thailand dan India.

Sejalan dengan perkembangan tersebut peranan sebagai pemerintah (Government) bergeser menjadi kepemerintahan (Governance). Pergeseran peran tersebut cenderung untuk memberikan peran lebih kepada masyarakat dan swasta. Berdasarkan peraturan pemerintah nomor 101 tahun 2000 disebutkan bahwa dalam paradigma kepemerintahan yang baik (Good Governance) terdapat prinsipprinsip profesionalitas, akuntabilitas, transparansi, pelayanan prima, demokrasi, efisiensi, efektifitas dan supremasi hukum. Indonesia terus berbenah, pemerintah dengan persetujuan DPR RI telah berhasil menetapkan paket perundang-undangan di bidang keuangan negara yaitu undang-undang Nomor 17 tahun 2003 tentang keuangan negara, undang-undang nomor 1 tahun 2004 tentang perbendaharaan negara, dan undang-undang nomor 15 tahun 2004 tentang pemeriksaan pengelolaan dan tanggung jawab keuangan negara sebagai dasar reformasi di bidang keuangan negara. Undangundang nomor 17 tahun 2003 menyebutkan bahwa masalah yang tidak kalah pentingnya dalam upaya memperbaiki proses penganggaran sektor publik adalah penerapan anggaran berbasis prestasi kerja.

Dalam rangka penerapan anggaran berbasis prestasi kerja atau berbasis kinerja tersebut perlu dilakukan penyatuan sistem akuntabilitas kinerja ke dalam sistem penganggaran, jika kedua hal ini tidak disatukan maka berpotensi terjadi duplikasi dalam penyusunan rencana kinerja dan rencana anggaran. Saat ini kegiatan pemerintah harus berorientasi pada kinerja atau hasil dan bukan lagi berorientasi pada biaya. Hasil yang diperoleh haruslah terukur dan menunjang pencapaian visi misi sesuai dengan tugas fungsi pemerintah masing-masing kementerian/lembaga/satuan kerja perangkat daerah. Penyusunan rencana-rencana pemerintah yang dituangkan dalam bentuk anggaran haruslah disusun secara seksama agar dapat digunakan sebagai pedoman dalam pelaksanaan tugas negara. Pentingnya anggaran bagi suatu organisasi ditegaskan oleh Izzetin dalam Sulistio (2010) bahwa penyusunan anggaran yang baik harus mempunyai karakteristik sebagai berikut: partisipasi dalam penyusunan anggaran, kejelasan sasaran anggaran, umpan balik anggaran, evaluasi anggaran dan tingkat kesulitan anggaran.

Sistem anggaran sektor publik di Indonesia telah berubah menjadi sistem anggaran berbasis kinerja (performance budgeting). Melalui anggaran berbasis kinerja diharapkan dalam pelaksanaannya pemerintah dapat mengedepankan proses bottom-up sehingga pengelolaan dan alokasi anggaran bisa lebih tepat, hemat, efektif dan efisien. Anggaran yang disusun hendaknya dapat mengakomodir kepentingan setiap kementerian/lembaga/satuan kerja perangkat daerah yang terkait dalam pelaksanaannya sehingga diperlukan partisipasi dari berbagai pihak dalam penyusunan anggaran.

Anggaran pada sektor publik terkait dengan proses penentuan jumlah alokasi dana untuk tiaptiap program dan aktivitas dalam satuan moneter yang menggunakan dana milik rakyat selain itu dapat digunakan juga untuk menilai kinerja para pimpinan sehingga dapat mempengaruhi perilaku dan kinerja manajerial. Dengan demikian maka anggaran dapat dijadikan alat pengendali atas rincian pendapatan dan pengeluaran yang dilakukan pemerintah untuk dipertanggungjawabkan kepada publik sehingga masyarakat dapat menilai kinerja manajer publik berdasarkan tingkat pencapaian dan efisiensi pelaksanaan anggaran. Agar anggaran dapat mencapai tujuan perusahaan maka karakteristik anggaran yang diperlukan antara lain adalah umpan balik berkala tentang kinerja, insentif moneter dan non-moneter, penganggaran partisipatif, standar realistis, pengendalian biaya, dan berbagai ukuran kinerja (Hansen dan Mowen, 2013).

Penganggaran partisipatif dapat memotivasi bawahan dan meningkatkan rasa tanggung jawab pribadi untuk mencapai tujuan anggaran yang dibuat karena mereka ikut serta terlibat dalam penyusunannya. Dalam organisasi sektor publik, tujuan pemerintah adalah yang tercantum dalam dokumen perencanaan strategik (Renstra) kemudian pada rencana kerja anggaran (RKA) dan menjadi dokumen pelaksanaan anggaran (DPA) setelah disetujui dan disahkan oleh dewan perwakilan rakyat (DPR). Berbagai studi dalam bidang akuntansi keperilakuan menyatakan bahwa hubungan antara penganggaran partisipatif (participative budgeting) dan kinerja cukup kompleks dan tidak selalu konsisten (Lau dan Tan dalam Hasniasari dan Solihin 2014) bahkan sudah menjadi isu yang banyak dijelaskan dalam literatur akuntasi manajemen yang secara empiris menyarankan bahwa partisipasi anggaran tidak memiliki dampak langsung terhadap kinerja tetapi harus ada variabel mediasi. Merchant dalam Hasniasari dan Sholihin (2014) menemukan bahwa pengaruh partisipasi pada penganggaran terhadap kinerja tidak signifikan. Peneliti lain menemukan hubungan antara partisipasi pada penganggaran dan kinerja adalah negatif sedangkan penelitian dari Magner dan Johnson dalam Hasniasari dan Sholihin (2014) mengemukakan bahwa keadilan persepsi (perceived fairness) adalah salah satu variabel penting yang dapat memediasi pengaruh partisipasi pada penganggaran terhadap 
kinerja. Penemuan ini sejalan dengan penelitian lain oleh Linquist (1995) dan Libby (1999) yang menemukan bahwa partisipasi dalam sebuah organisasi memungkinkan adanya rasa diperlakukan dengan adil sehingga dapat mendorong pegawai tersebut untuk meningkatkan kinerja. Wentzel (2002) membuktikan bahwa persepsi keadilan memediasi pengaruh antara penganggaran partisipatif dan komitmen terhadap tujuan sedangkan komitmen terhadap tujuan memediasi pengaruh antara persepsi keadilan dan kinerja. Penelitian oleh Hasniasari dan Sholihin (2014) menunjukkan bahwa penganggaran partisipatif berpengaruh dengan sangat signifikan pada keadilan distributif, keadilan prosedural, dan komitmen terhadap tujuan.

Persepsi keadilan berkaitan dengan perasaan pegawai terhadap rasa adil seorang pegawai di mana input yang diberikan pada perusahaan dibayar sesuai dengan sebagaimana mestinya. Penganggaran partisipatif yang baik akan menumbuhkan rasa adil bagi pegawai sehingga kinerjanya meningkat. Selain itu penganggaran partisipatif dapat meningkatkan komitmen terhadap organisasi karena para pegawai merasa punya tanggungjawab atas anggaran yang telah disusun sehingga berusaha untuk mencapai tujuan anggaran tersebut yang juga merupakan tujuan perusahaaan.

Sejak 2011-2014 Kementerian Agama mendapat opini Wajar Tanpa Pengecualian Dengan Paragraf Pengecualian (WTP DPP) dari Badan Pemeriksa Keuangan (BPK) namun pada tahun 2015 mengalami penurunan dengan mendapat opini Wajar Dengan Pengecualian (WDP). Ditahun berikutnya Kementerian Pendayagunaan Aparatur Negara dan Reformasi Birokrasi merilis hasil evaluasi kinerja tahun 2015 dimana Kementerian Agama mendapat nilai 62,01 atau nilai B setelah sebelumnya mendapat nilai 54,83 atau C padahal realisasi anggaran tahun 2015 mencapai 88,86\% dan menduduki peringkat ketiga nasional. Kementerian Agama Provinsi Sulawesi Utara sendiri mampu menyerap anggaran sebesar 89,15\% dari total Pagu Anggaran Rp.511.602.212.000. Tak dapat dipungkiri kinerja dan serapan anggaran di daerah mempengaruhi penilaian pada Kementerian Agama.

Berdasarkan UU No. 32 tahun 2004, sistem pemerintahan yang pada awalnya menganut pola sentralisasi beralih menjadi pola desentralisasi yang mengakibatkan pergeseran orientasi pemerintah dari command and control menjadi berorientasi pada tuntutan dan kebutuhan publik.

Kementerian Agama Provinsi Sulawesi Utara adalah perpanjangan tangan dari Kementerian Agama RI yang sampai saat ini terdapat 128 satuan kerja. Walaupun Kementerian Agama merupakan salah satu kementerian/lembaga negara yang tersentralisasi, namun Kementerian Agama tetap memperioritaskan azas desentralisasi dalam hal pengalokasian anggaran sesuai UU No. 25 Tahun 1999 tentang perimbangan keuangan antara pemerintah pusat dan daerah. Alokasi anggaran pusat dan daerah pada anggaran Kementerian Agama lebih besar diperuntukkan bagi daerah. Penelitian dari Riyadi (2000) menyatakan bahwa interaksi antara partisipasi penyusunan anggaran dengan pelimpahan wewenang yang terdesentralisasi akan meningkatkan kinerja manajerial.

Penerapan penganggaran partisipatif yang baik akan meningkatkan rasa adil bagi para pegawai dan meningkatkan komitmen terhadap organisasi serta peningkatan kinerja manajerial. Selain itu desentralisasi yang tinggi dapat meningkatkan pengaruh penganggaran partisipatif terhadap kinerja manajerial pada Kementerian Agama Provinsi Sulawesi Utara.

Penelitian ini mempunyai tujuan untuk mengetahui:

1) Pengaruh penganggaran partisipatif terhadap kinerja manajerial yang dimediasi oleh persepsi keadilan

2) Pengaruh penganggaran partisipatif terhadap kinerja manajerial yang dimediasi oleh komitmen organiasasi

3) Pengaruh penganggaran partisipatif terhadap kinerja manajerial yang dimoderasi oleh desentralisasi

Gambar 1.

Kerangka Konseptual

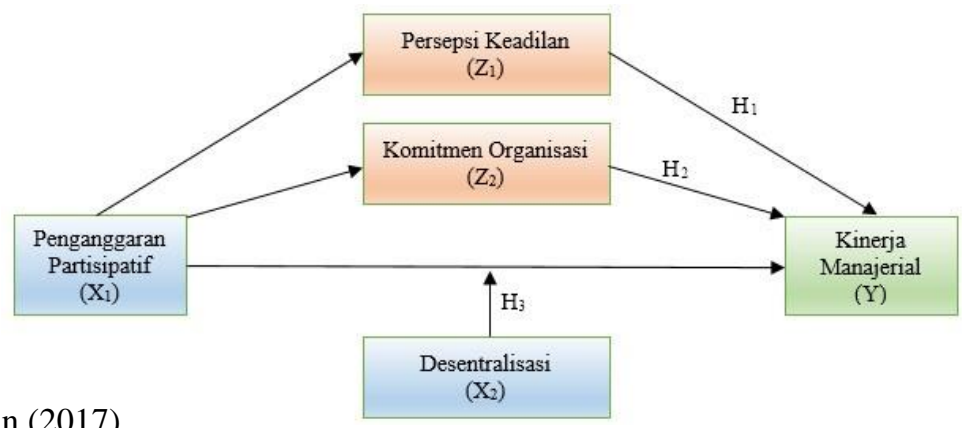

Sumber: Hasil Data Olahan (2017) 
Berdasarkan Gambar 1. bentuk penelitian menunjukkan suatu pengaruh antara variabel independen atau variabel bebas yaitu Penganggaran Partisipatig terhadap variabel dependen atau variabel terikat yaitu Kinerja Manajerial, dimediasi oleh variabel mediasi yang terdiri dari Persepsi Keadilan, dan Komitmen Organisasi, serta dimoderasi oleh variabel moderating yaitu Desentralisasi.

Berdasarkan kajian teoritis, hasil-hasil penelitian terdahulu, serta kerangka pemikiran teoritis, maka peneliti merumuskan hipotesis, sebagai berikut.

\section{Persepsi Keadilan $\left(Z_{1}\right)$ Memediasi Pengaruh Penganggaran Partisipatif $\left(X_{1}\right)$ terhadap}

Kinerja Manajerial (Y)

Dengan dilibatkan dalam proses penganggaran maka persepsi individu terhadap keadilan akan meningkat, ketika pegawai merasa diperlakukan secara adil dalam perusahaan maka kinerjanya akan meningkat. Meningkatnya persepsi keadilan saat seseorang diberikan kesempatan untuk berpartisipasi karena mereka meyakini proses partisipasi tersebut penting untuk mencapai tujuan yang diharapkan (Hasniasari dan Sholihin, 2014). Dari uraian diatas, hipotesis dapat dirumuskan sebagai berikut:

$H_{1}$ : Persepsi keadilan memediasi pengaruh antara penganggaran partisipatif terhadap kinerja manajerial

2. Komitmen Organisasi $\left(\mathbf{Z}_{2}\right)$ Memediasi Pengaruh Penganggaran Partisipatif $\left(\mathbf{X}_{1}\right)$ terhadap Kinerja Manajerial (Y)

Penganggaran partisipatif tidak memiliki efek langsung terhadap kinerja, melainkan dikondisikan pada variabel intervening lain (Shields dan Young, 1998). Komitmen organisasi menjadi variabel yang perlu dipertimbangkan untuk melihat pengaruh antara partisipasi anggaran dan kinerja karena memungkinkan adanya kecukupan anggaran yang bisa menimbulkan komitmen yang kuat bagi para manager untuk untuk berusaha keras mencapai tujuan organisasi dan menghasilkan kinerja yang baik. Kecukupan anggaran dan komitmen organisasi yang tinggi akan meningkatkan kinerja. Oleh karena itu dapat dikatakan bahwa partisipasi anggaran berpengaruh terhadap kinerja melalui komitmen organisasi. Dari uraian tersebut hipotesis dapat dirumuskan sebagai berikut:

\section{$\mathrm{H}_{2}$ : Komitmen Organisasi memediasi Pengaruh antara penganggaran partisipatif terhadap kinerja} manajerial

3. Desentralisasi $\left(\mathbf{X}_{2}\right)$ Memoderasi Pengaruh Antara Penganggaran Partisipatif $\left(\mathbf{X}_{1}\right)$ Dengan Kinerja Manajerial (Y)

Desentralisasi atau Pelimpahan wewenang merupakan suatu pemberian yang menjadi hak atas tugas dan tanggung jawab untuk melakukan sesuatu atau memerintah orang lain untuk melakukan sesuatu. Sebagaimana dikatakan Mulyadi dalam Suwarno, dkk (2013) pelimpahan wewenang adalah pemberian wewenang oleh manajer yang lebih tinggi kepada manajer yang lebih rendah untuk melaksanakan suatu pekerjaan dengan otorisasi secara eksplisit dari manajer pemberi wewenang pada waktu wewenang tersebut dilaksanakan.

Hasil penelitian dari Riyadi (2000) menemukan bahwa penganggaran partisipatif berpengaruh positif terhadap kinerja apabila pelimpahan wewenang yang diberikan pada tingkat desentralisasi yang tinggi. Penelitian lain dari Hapsari dan Murtanto (2005) juga menemukan interaksi antara variabel penganggaran partisipatif dan desentralisasi mempengaruhi kinerja manajerial. Hipotesis dapat dirumuskan sebagai berikut:

$\mathrm{H}_{3}$ : Desentralisasi memoderasi Pengaruh Penganggaran Partisipatif terhadap Kinerja Manajerial.

\section{Metode Penelitian}

Penelitian ini merupakan jenis penelitian kuantitatif yang bertujuan untuk mengetahui pengaruh penganggaran partisipatif terhadap kinerja manajerial dengan persepsi keadilan dan komitmen organisasi sebagai variabel mediasi dan desentralisasi sebagai variabel moderasi. Teknik analisis yang digunakan adalah analisis jalur. Penelitian ini dilakukan pada Kementrian Agama Provinsi Sulawesi Utara. Populasi yang digunakan adalah seluruh kepala kantor, kepala bidang/pembimas, kepala seksi/penyelenggara di satuan kerja (Satker) Kementrian Agama yang ada di Provinsi Sulawesi Utara yang berjumlah 171 orang. Metode yang digunakan dalam penarikan sampel ini adalah sampel dengan tujuan tertentu (purposive sampling) yang berjumlah 136 responden.

Indikator Penganggaran Partisipatif menurut Milani (1975) yaitu: 1) keterlibatan dalam proses penyusunan anggaran; 2) intensitas atasan menjelaskan revisi anggaran; 3) frekuensi diskusi dengan atasan tentang anggaran yang disusun; 4) memiliki tujuan yang dicapai dalam anggaran akhir; 5) kontribusi untuk anggaran menjadi penting. 
Indikator Persepsi Keadilan menurut Greenberg (1986) yaitu: keadilan distributif yaitu 1) tanggung jawab diterima dalam anggaran yang dapat dipertanggungjawabkan; 2) anggaran teralokasi untuk tanggungjawab merefleksikan kebutuhan; 3) tanggung jawab anggaran adalah apa yang diharapkan; 4) pembatasan wilayah tanggung jawab menuju keterbukaan; 5) ekspresi supervisor, perhatian dan kepekaan ketika mendiskusikan anggaran tempat batasan area tanggung jawab. Selanjutnya ada keadilan prosedural yaitu: 1) prosedur penganggaran diaplikasikan secara konsisten dengan semua area tanggung jawab; 2) prosedur penganggaran diaplikasikan secara konsisten dengan waktu; 3) keputusan penganggaran untuk area pertanggungjawaban berdasarkan informasi akurat dan opini yang diinformasikan secara baik; 4) perhatian prosedur penganggaran berisi ketentuan tentang pertanggungjawaban; 5) prosedur penganggaran yang sedang berjalan mengkonfirmasi standar etika dan moralitas; 6) penentu keputusan penganggaran mencoba dengan keras tidak untuk area tanggung jawab atau yang lain; 7) prosedur penganggaran yang sedang berjalan representasi yang memadahi perhatian pada area tanggung jawab; 8) penentu keputusan penganggaran menjelaskan bagaimana alokasi anggaran untuk pertanggung jawaban.

Indikator komitmen organisasi menurut Allen dan Meyer (1997) yaitu: 1) komitmen afektif (affective commitmen) berkaitan dengan emosional, keterlibatan dan identifikasi pegawai di dalam suatu organisasi; 2) komitmen berkelanjutan (continuance commitment) berarti komponen berdasarkan persepsi pegawai tentang kerugian yang akan dihadapi jika ia meninggalkan organisasi; 3) komitmen Normatif (normative commitment) merupakan perasaan-perasaan pegawai tentang kewajiban yang harus ia berikan kepada organisasi.

Indikator desentralisasi menurut Simamora (1999) ada empat kunci dalam penerapan desentralisasi yaitu: 1) delegasi; 2) wewenang; 3) tanggung jawab; 4) akuntabilitas. Indikator kinerja manajerial menurut Mahoney, dkk (1963) yaitu: 1) perencanaan/Planning; 2) investigasi/investigation; 3) koordinasi/coordination; 4) evaluasi/evaluation; 5) supervisi/supervison; 6) penyusunan staf/staffing; 7) negosiasi/negotiation; 8) representasi/representation.

Persamaan-persamaan regresi yang digunakan dalam penelitian ini diuji dengan signifikansi $5 \%$, model persamaan regresi penelitian ini adalah:

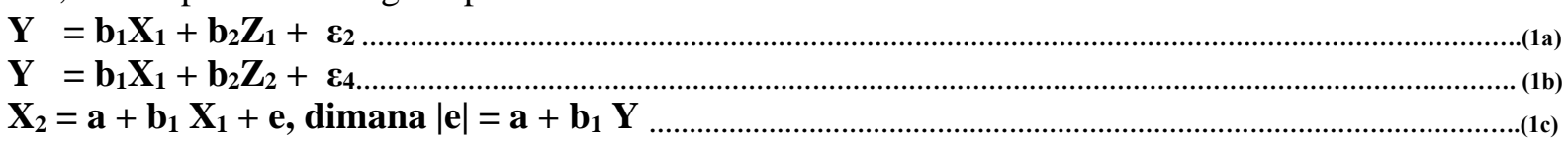

\section{Hasil Penelitian dan Pembahasan}

Data dalam penelitian ini dikumpulkan dengan cara menyebarkan kuesioner langsung kepada 136 responden. Dari jumlah yang disebarkan tersebut terkumpul sebanyak 112 kuesioner. Uji validitas dilakukan dengan uji homogenitas data dengan melakukan uji korelasional antara skor masing-masing item dengan skor total (Pearson Correlation). Pengujian ini dimaksudkan untuk mengetahui apakah semua pertanyaan (instrumen) penelitian yang diajukan untuk mengukur variabel dapat dipakai. Jika $r$ hitung lebih besar dari $r$ tabel, maka skor butir pertanyaan/pernyataan kuesioner valid, tetapi sebaliknya jika $r$ hitung lebih kecil dari $r$ tabel, maka skor butir pertanyaan/pernyataan tidak valid. Peneliti telah melakukan uji validitas untuk setiap pertanyaan dari kuesioner dan hasil yang diperoleh dari masing-masing pertanyaan adalah valid.

Uji reliabilitas dimaksudkan untuk mengetahui sejauh mana hasil pengukuran konsisten, apabila dilakukan pengukuran dua kali atau lebih terhadap gejala yang sama dengan menggunakan alat pengukur yang sama. Peneliti melakukan uji reliabilitas dengan menghitung cronbach's alpha dari masing-masing instrumen dalam suatu variabel. Instrumen yang dipakai dalam variabel tersebut dikatakan andal (reliable) apabila memiliki cronbach's alpha lebih dari 0.60. Hasil uji reliabilitas yang didapat peneliti untuk setiap variabel berdasarkan output SPSS adalah $>0.60$ sehingga dapat dikatakan bahwa variabel-variabel tersebut reliabel.

Setelah model ditentukan langkah selanjutnya adalah Uji Prasyarat Analisis Jalur, persyaratan yang harus dipenuhi sebelum suatu analisis diterapkan pada sebuah data yang terdiri dari:

Uji Normalitas dilakukan untuk mengetahui apakah data sampel memenuhi persyaratan distribusi normal. Persyaratan data tersebut normal jika probabilitas atau $\mathrm{p}>0.05$ pada uji normalitas dengan Kolmogorov-Smirov (K-S). Hasil uji normalitas dinyatakan memenuhi persyaratan distribusi normal.

Uji Heteroskedastisitas digunakan untuk menguji apakah dalam model regresi terjadi ketidaksamaan varian dari residual pada satu pengamatan yang lain. Model regresi yang baik adalah 
tidak terjadi heteroskedastisitas. Hasil pengujian diagram pencar residual tidak membentuk suatu pola tertentu atau posisinya dalam keadaan menyebar sehingga dapat disimpulkan model regresi terbebas dari kasus heterokedastisitas.

Uji Linieritas dimaksudkan untuk mengetahui garis hubungan antara variabel bebas terhadap variabel terikat berbentuk linier atau tidak. Dalam analisis jalur hubungan antar variabel harus linier (Linearity) dan tidak ada efek interaksi (Additivity). Uji linearitas menggunakan curve fit dan menerapkan prinsip parsimony yaitu bilamana seluruh model signifikan atau non signifikan berarti dapat dikatakan model berbentuk linier. Hasil uji linieritas yang didapat menunjukkan bahwa seluruh model signifikan, berarti dapat disimpulkan bahwa model berbentuk linier.

\section{Pengujian Hipotesis 1}

Hasil pengujian persepsi keadilan memediasi pengaruh penganggaran partisipatif terhadap kinerja manajerial diperoleh nilai standardized beta penganggaran partisipatif sebesar 0,354 dengan nilai signifikan pada 0,000 yang berarti penganggaran partispatif mempengaruhi persepsi keadilan. Nilai koefisien standardized beta 0,354 merupakan nilai path atau jalur p2. Nilai standardized beta pada tabel 5 untuk penganggaran partisipatif 0,356 dan persepsi keadilan 0,292 semuanya signifikan. Nilai standardized beta penganggaran partisipatif 0,356 merupakan nilai jalur $\mathrm{p} 1$ dan nilai standardized beta persepsi keadilan 0,292 merupakan nilai jalur path p3. Besar nilai $\varepsilon_{1}=\sqrt{ } 1-0,126=$ 0,935 dan nilai $\varepsilon_{2}=\sqrt{ } 1-0,286=0,845$. Hasil persamaan regresi diatas dapat digambarkan sebagai berikut:

\section{Gambar 2}

Struktur $\left(\mathrm{Z}_{1}\right)$ memediasi pengaruh $\left(\mathrm{X}_{1}\right)$ terhadap $(\mathrm{Y})$

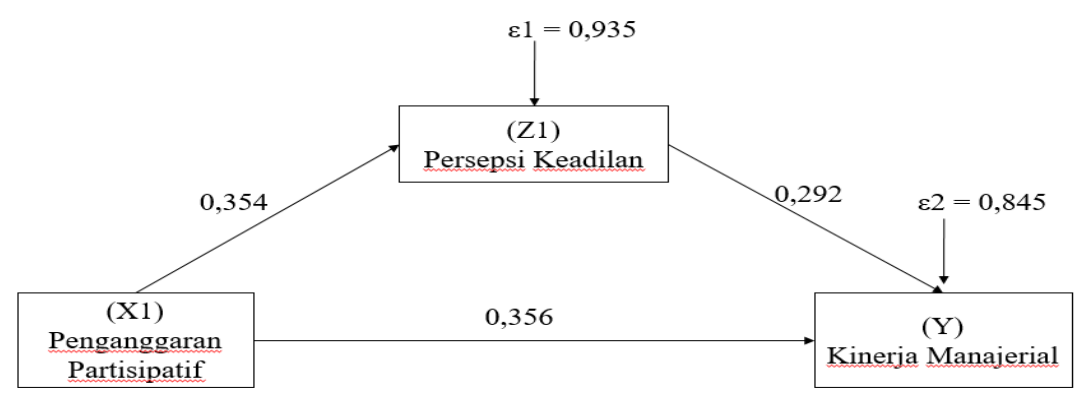

Sumber: Hasil Olahan Data (2017)

Persamaan strukturnya adalah :

1. $\mathrm{Z}_{1}=0,354 \mathrm{X}_{1}+0,935$

2. $\mathrm{Y}=0,356 \mathrm{X}_{1}+\mathbf{0 , 2 9 2} \mathrm{Z}_{1}+\mathbf{0 , 8 4 5}$

Hasil ini menunjukan bahwa Persepsi keadilan memediasi pengaruh antara penganggaran partisipatif terhadap kinerja manajerial

\section{Pengujian Hipotesis 2}

Hasil pengujian persepsi keadilan memediasi pengaruh penganggaran partisipatif terhadap kinerja manajerial diperoleh nilai standardized beta penganggaran partisipatif sebesar 0,292 dengan nilai signifikan pada 0,002 yang berarti penganggaran partispatif mempengaruhi komitmen organisasi. Nilai koefisien standardized beta 0,292 merupakan nilai path atau jalur $\mathrm{p} 5$.

Nilai standardized beta pada tabel 9 untuk penganggaran partisipatif 0,364 dan komitmen organisasi 0,326 semuanya signifikan. Nilai standardized beta penganggaran partisipatif 0,364 merupakan nilai jalur $\mathrm{p} 4$ dan nilai standardized beta komitmen organisasi 0,326 merupakan nilai jalur p5. Besar nilai $\varepsilon_{3}=\sqrt{1}-0,085=0,956$ dan nilai $\varepsilon_{4}=\sqrt{ } 1-0,308=0,831$. Hasil persamaan regresinya dapat digambarkan sebagai berikut: 


\section{Gambar 2}

Struktur $\left(\mathrm{Z}_{2}\right)$ memediasi pengaruh $\left(\mathrm{X}_{1}\right)$ terhadap $(\mathrm{Y})$

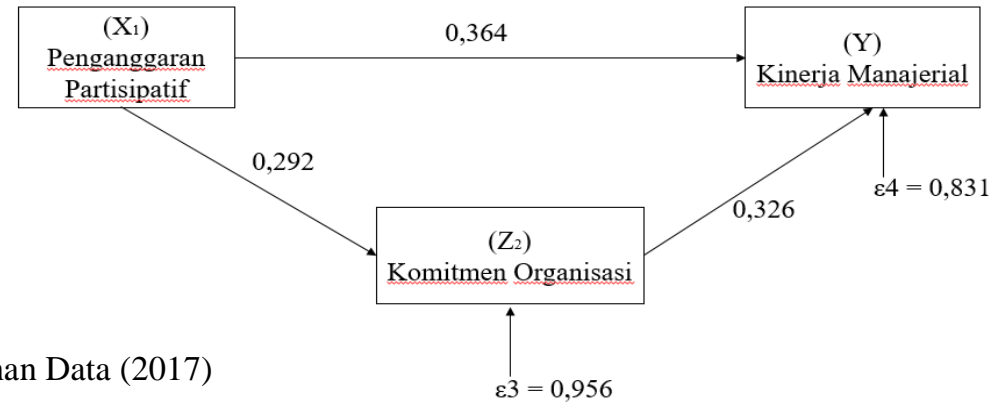

Persamaan strukturnya adalah:

1. $Z_{2}=0,292 X_{1}+0,956$

2. $Y=0,364 X_{1}+0,326 Z_{2}+0,831$

Hasil diatas menunjukan bahwa Komitmen organisasi memediasi pengaruh antara penganggaran partisipatif terhadap kinerja manajerial

\section{Pengujian Hipotesis 3}

Pengujian desentralisasi memoderasi pengaruh penganggaran partisipatif terhadap kinerja manajerial dilakukan dengan uji residual. Hasil yang diperoleh adalah angka koefisien regresi bernilai positif $(0.026)$ dan tidak signifikan $(0.217>0.05)$ Jadi dapat disimpulkan bahwa desentralisasi tidak memoderasi hubungan antara penganggaran partisipatif dengan kinerja manajerial atau desentralisasi bukan merupakan variabel moderasi. Hasil penelitian ini tidak memperoleh dukungan yang signifikan terhadap teori yang menyatakan bahwa desentralisasi memperkuat pengaruh antara penganggaran partisipatif terhadap kinerja manajerial.

\section{Persepsi Keadilan $\left(Z_{1}\right)$ Memediasi Pengaruh Antara Penganggaran Partisipatif (X1) terhadap Kinerja Manajerial (Y)}

Persepsi keadilan memediasi pengaruh antara penganggaran partisipatif terhadap kinerja manajerial. Hasil pengujian pengaruh variabel tersebut diperoleh t hitung untuk penganggaran partisipatif sebesar 4,109 dan persepsi keadilan sebesar 3,374 > t tabel 1,982 dengan nilai signifikan < 0,05 maka disimpulkan bahwa variabel penganggaran partisipatif dan persepsi keadilan berpengaruh dan signifikan terhadap variabel kinerja manajerial. Pengaruh langsung yang diberikan $\left(\mathrm{X}_{1}\right)$ terhadap (Y) sebesar 0,354. Sedangkan pengaruh tidak langsung $\mathrm{X}_{1}$ terhadap $\mathrm{Y}$ melalui $\mathrm{Z}_{1}$ adalah $(0,354 \mathrm{x}$ $0,292)=0,103$. Maka pengaruh total yang diberikan $X_{1}$ terhadap $Y$ adalah pengaruh langsung ditambah pengaruh tidak langsung yaitu: $0,356+0,103=0,459$.

Dengan demikian hasil penelitian ini menyatakan bahwa Persepi Keadilan $\left(\mathrm{Z}_{1}\right)$ memediasi pengaruh antara penganggaran partisipatif $\left(\mathrm{X}_{1}\right)$ terhadap kinerja manajerial $(\mathrm{Y})$. Seperti yang telah dijelaskan dalam stewardship theory bahwa bukan tujuan individu yang diutamakan melainkan kepentingan dari organisasi yang diutamakan yaitu Kementerian Agama Provinsi Sulawesi Utara. Ketika pegawai dilibatkan dalam proses penganggaran maka persepsi keadilan akan meningkat dan akhirnya kinerja manajerialpun meningkat. Hal ini sangat penting, terutama di organisasi sektor publik seperti Kementerian Agama Provinsi Sulawesi Utara semakin baik kinerja manajerial maka rakyat selaku principal akan semakin sejahtera.

Jika dihubungkan dengan hasil penelitian terdahulu, hasil ini sesuai dengan penelitian Abata (2014) yang menemukan ada pengaruh signifikan antara penganggaran partisipatif $\left(X_{1}\right)$ terhadap kinerja manajerial. Hasil penelitian yang serupa juga ditemukan oleh Apriwandi dan Chaeruba (2012) yang melakukan penelitian pada rumah sakit di Provinsi Jawa Tengah dimana hasilnya menunjukan bahwa ada pengaruh positif antara penganggaran partisipatif terhadap kinerja manajerial baik secara langsung maupun secara tidak langsung dengan melalui persepsi keadilan. Penelitian lain yang dilakukan oleh Hasniasari dan Sholihin (2014) juga menemukan bahwa penganggaran partisipatif berpengaruh secara positif dan signifikan terhadap kinerja manajerial. 


\section{Komitmen Organisasi $\left(Z_{2}\right)$ Memediasi Pengaruh Penganggaran Partisipatif $\left(X_{1}\right)$ berpengaruh terhadap Kinerja Manajerial (Y)}

Komitmen organisasi memediasi pengaruh antara penganggaran partisipatif terhadap kinerja manajerial. Hasil pengujian pengaruh variabel tersebut diperoleh t hitung untuk penganggaran partisipatif sebesar 4,369 dan komitmen organisasi sebesar 3,920>t tabel 1,982 dengan nilai signifikan $<0,05$. Pengaruh langsung yang diberikan $\left(\mathrm{X}_{1}\right)$ terhadap $(\mathrm{Y})$ sebesar 0,354 . Sedangkan pengaruh tidak langsung $X_{1}$ terhadap $Y$ melalui $Z_{2}$ adalah $(0,326 \times 0,292)=0,095$. Maka pengaruh total yang diberikan $\mathrm{X}_{1}$ terhadap $\mathrm{Y}$ adalah pengaruh langsung ditambah pengaruh tidak langsung yaitu: $0,364+0,095=0,459$.

Melihat hasil diatas, maka dapat dinyatakan bahwa kinerja manajerial pada Kementerian Agama provinsi Sulawesi Utara meningkat ketika penganggaran partisipatif yang dimediasi oleh komitmen organisasi meningkat. Ketika para pegawai atau pejabat pelaksana berpartisipasi dalam penyusunan anggaran dan disepakati maka komitmen mereka untuk melaksanakan kegiatan sesuai dengan anggaran tersebut akan meningkat, yang artinya komitmen organisasi tersebut meningkat sehingga kinerja manajerial juga meningkat. Hasil ini sama dengan penelitian oleh Jermias dan Setiawan (2008) yang melakukan penelitian mengenai penganggaran di organisasi sektor publik di Indonesia di bidang keuangan yang menemukan bahwa penganggaran partisipatif meningkatkan kinerja manajerial dengan komitmen organisasi. Penelitian lain oleh Hasniasari dan Sholihin (2014) yang melakukan penelitian mengenai penganggaran partisipatif dan kinerja pada lembaga hukum sektor publik di Indonesia juga menemukan hasil yang sama dimana kinerja dipengaruhi secara positif oleh penganggaran partisipatif dan komitmen organisasi. Penelitian oleh Lincoln dan Kalleberg (1985) juga menemukan kinerja manajerial mengingkat ketika penganggaran partisipatif dan komitmen organisasi meningkat.

\section{Desentralisasi $\left(\mathbf{X}_{2}\right)$ Memoderasi Pengaruh Antara Penganggaran Partisipatif $\left(\mathbf{X}_{1}\right)$ terhadap Kinerja Manajerial (Y)}

Dari hasil output angka koefisien regresi bernilai positif (0.026) dan tidak signifikan $(0.217>$ 0.05). Jadi dapat disimpulkan bahwa desentralisasi tidak memoderasi pengaruh antara penganggaran partisipatif dengan kinerja manajerial atau desentralisasi bukan merupakan variabel moderasi.

Hasil penelitian ini tidak memperoleh dukungan yang signifikan terhadap teori yang menyatakan bahwa desentralisasi memperkuat pengaruh antara penganggaran partisipatif terhadap kinerja manajerial. Meskipun Kementerian Agama Provinsi Sulawesi Utara mengatakan telah menggunakan sistem multi DIPA dan proses perencanaan dan penganggaran dilaksanakan secara bottom-up namun pelimpahan wewenang atau desentralisasi belum berjalan dengan baik sehingga hasil yang didapat dari penelitian ini adalah variabel desentralisasi bukan merupakan variabel moderasi pada pengaruh variabel penganggaran partisipatif terhadap kinerja manajerial.

Hasil ini tidak sesuai dengan penelitian dari Riyadi (2000) yang membuktikan bahwa interaksi antara penganggaran partisipatif dengan pelimpahan wewenang secara positif dan signifikan mempengaruhi kinerja manajerial. Namun penelitian ini mendapat hasil yang sama dengan penelitian oleh Nazaruddin dan Setyawan (2012) yang melakukan penelitian di Pemerintah Daerah Kulon Progo bahwa penganggaran partisipasi tidak berpengaruh terhadap kinerja yang dimoderasi oleh desentralisasi. Beberapa faktor yang mungkin menjadi penyebab desentralisasi bukan variabel moderasi pada penganggaran partisipatif terhadap kinerja manajerial adalah pengaturan porsi anggaran yang dirasa kurang pas. Selain itu kebijakan-kebijakan oleh pemerintah pusat terkadang terlalu membatasi para pegawai daerah, sehingga desentralisasi tidak terlalu terasa. Indonesia merupakan negara yang memiliki banyak kepulauan dengan berbagai suku dan latar belakang yang beraneka ragam, kebijakan atau aturan yang baik di suatu daerah belum tentu baik dan efektif jika dijalanan di daerah lain. Walaupun penganggaran partisipatif sudah dijalankan dan para pegawai terlibat dalam proses penyusunan anggaran, namun hasil akhirnya ditentukan oleh pemerintah pusat.

Kementerian Agama Provinsi Sulawesi Utara harus lebih proaktiv dalam memperjuangkan perencanaan anggaran yang telah disusun sambil terus memperbaharui dan mengakomodir kebutuhankebutuhan di masing-masing kabupaten/kota yang ada di Sulawesi Utara. Untuk saat ini penganggaran partisipatif sudah berjalan dengan baik, namun kelihatan bahwa anggaran yang disusun hanya menyesuaikan dengan porsi anggaran yang diatur oleh pemerintah pusat. 


\section{Kesimpulan dan Saran}

Berdasarkan pembahasan dan hasil analisa dari penelitian yang sudah dilakukan, maka diperoleh kesimpulan sebagai berikut:

1. Persepsi keadilan memediasi pengaruh antara penganggaran partisipatif terhadap kinerja manajerial pada Kementerian Agama Provinsi Sulawesi Utara, artinya para pegawai di Kementerian Agama Provinsi Sulawesi Utara khususnya para pejabat atau manager pada sektor publik merasa dilibatkan pada proses penganggaran. Hal ini menyebabkan mereka merasa lebih adil antara yang dikerjakan dan yang diterima sehingga kinerja merekapun meningkat.

2. Komitmen organisasi memediasi pengaruh antara penganggaran partisipatif terhadap kinerja manajerial pada Kementerian Agama Provinsi Sulawesi Utara. Hal ini berarti partisipasi para pejabat atau manager pada sektor publik di Kementerian Agama Provinsi Sulawesi Utara dalam menyusun anggaran meningkatkan komitmen mereka terhadap organisasi karena merasa turut bertanggung jawab atas anggaran yang mereka susun sehingga kinerja manajerialpun turut meningkat.

3. Desentralisasi tidak memoderasi pengaruh antara penganggaran partisipatif terhadap kinerja manajer, walaupun seperti yang diketahui bahwa Kementerian Agama sudah menerapkan sistem multi DIPA dan proses penganggaran dilaksanakan secara bottom-up. Hal ini bisa disebabkan kurangnya pelimpahan wewenang dan tanggung jawab atau desentralisasi pada daerah sehingga masih terbatas dan banyak yang terpusat di Kementerian Agama Republik Indonesia mengingat Kementerian Agama merupakan instansi vertikal. berikut:

Berdasarkan hasil penelitian yang dilakukan adapun saran yang dapat diberikan sebagai

1. Perlu mempertahankan dan meningkatkan keterlibatan para pegawai dalam proses penyusunan anggaran, hal ini bisa berdampak pada persepsi mereka yang akan merasa lebih adil sehingga komitmen untuk berkeja mencapai tujuan dan loyalitas bisa meningkat. Jika itu bisa dilaksanakan dengan baik maka secara otomatis kinerjapun akan meningkat.

2. Desentralisasi dalam penganggaran partisipatif juga perlu ditingkatkan pada Kementerian Agama Provinsi Sulawesi Utara supaya pengganggaran yang berbasis kinerja bisa berjalan dengan baik sehingga tujuan organisasi yang tertuang dalam visi dan misi bisa terealisasi.

3. Penelitian ini dilakukan dengan keterbatasan antara lain menggunakan lima variabel yaitu penganggaran partisipatif, persepsi keadilan, komitmen organisasi, desentralisasi dan kinerja manajerial dengan menggunakan analisis jalur untuk menguji pengaruh tidak langsung melalui variabel mediasi dan uji residual untuk variabel moderasi. Oleh karena itu ada keterbatasan pada penelitian ini maka disarankan pada penelitian selanjutnya selain menggunakan analisis jalur dapat juga menggunakan Structural Equation Modelling (SEM).

\section{Daftar Pustaka}

Abata, A. Mathew. 2014. Participative Budgeting and Managerial Performance in The Nigerian Food Products Sector. Global Journal of Contemporary Research in Accounting, Auditing and Business Ethics. Vol. 1, Issue 3.

Allen, J. N., and Meyer, J.P. 1997. Commitment in The Workplace: Theory Research and Application. California: Sage.

Apriwandi., dan Chaeruba, Yuma Ardilla. 2012. "Pengaruh Aspek Keperilakuan Akuntansi Manajemen Terhadap Kinerja Manajer Dalam Partisipasi Anggaran: Studi Kasus Pada Manajer Rumah Sakit Se-Jawa Tengah. Journal and Proceeding Seminar Nasional \& Call for Papers (SCA-3) Vol.3, No.1.

Greenberg, J. 1986. Determinants of perceived fairness of performance evaluations. Journal of Applied Psychology. Vol. 71, No. 2.

Hansen, Don R., dan Mowen, Maryanne. M. 2013. Akuntansi Manajerial. Buku 1 Edisi 8. Jakarta: Salemba Empat.

Hapsari, Winda Arum., dan Murtanto. 2005. Pengaruh Partisipasi Penyusunan Anggaran Terhadap Kinerja Manajerial dengan Desentralisasi dan Karakteristik Sistem Informasi Akuntansi Manajemen Sebagai Variable Moderating. Simposium Riset Ekonomi II. Surabaya, 23 -24 November 2005 
Hasniasari, Rahmia., dan Sholihin, Mahfud. 2014. Analisis Hubungan Penganggaran Partisipatif dan Kinerja: Pengujian Efek Mediasi Keadilan Persepsian dan Komitmen pada Lembaga Hukum Sektor Publik di Indonesia. Jurnal Akuntansi dan Keuangan Vol.16, No.1. Mei 2014

Jermias, J., and Setiawan, T. 2008. The Moderating Effects of Hierarchy and Control Systems on the Relationship between Budgetary Participation and Performance. The International Journal of Accounting. Vol. 43, No.3.

Libby, T. 1999. The influence of voice and explanation on performance in a participative budgeting setting. Accounting, Organization and Society. Vol. 24.

Lincoln, J.R., and Kalleberg, A.I. 1985. Work organization and workplace commitment a study of plants and employees in the U.S. and Japan. American Sociological Review. Vol. 50, No. 6.

Linquist, T. M. 1995. Fairness as an antecedent to participative budgeting: examining the effects of distributive justice, procedural justice and referent cognitions on satisfaction and performance. Journal of Management Accounting Research, Vol. 7.

Mahoney, T.A., Jerdee, T.H., and Caroll, S.J. 1963. Development of managerial Performance: A Research Approach. Cincinnati: South Western Publishing Company.

Milani, K.W. 1975. The Relationship of Participation in Budget-Setting to Industrial Supervisor Performance and Attitudes: a Field Study. The Accounting Review. Vol.50, No. 2.

Nazaruddin, Ietje., dan Setyawan, Henry. 2012. Pengaruh Partisipasi Penyusunan Anggaran Terhadap Kinerja Aparat Pemerintah Daerah dengan Budaya Organisasi, Komitmen Organisasi, Motivasi, Desentralisasi dan Job Relevant Information sebagai Variabel Moderasi. Jurnal Akuntansi dan Investasi. Vol. 12, No. 2.

Republik Indonesia. 1999. Undang-Undang No. 25 Tahun 1999 tentang Perimbangan Keuangan Antara Pemerintah Pusat dan Daerah. Lembaran Negara RI Tahun 1999, No. 72. Sekretariat Negara. Jakarta.

Republik Indonesia. 2000. Peraturan Pemerintah No. 101 Tahun 2000 tentang Pendidikan dan Pelatihan Jabatan Pegawai Negeri Sipil. Lembaran Negara RI Tahun 2000, No. 198. Sekretariat Negara. Jakarta.

Republik Indonesia. 2003. Undang-Undang No. 17 Tahun 2003 tentang Keuangan Negara. Lembaran Negara RI Tahun 2003, No. 47. Sekretariat Negara. Jakarta.

Republik Indonesia. 2004. Undang-Undang No. 1 Tahun 2004 tentang Perbendaharaan Negara. Lembaran Negara RI Tahun 2004, No. 5. Sekretariat Negara. Jakarta.

Republik Indonesia. 2004. Undang-Undang No. 15 Tahun 2004 tentang Pemeriksaan Pengelolaan dan Tanggung Jawab Keuangan Negara. Lembaran Negara RI Tahun 2004, No. 66. Sekretariat Negara. Jakarta.

Republik Indonesia. 2004. Undang-Undang No. 32 Tahun 2004 tentang Pemerintah Daerah. Lembaran Negara RI Tahun 2004, No. 125. Sekretariat Negara. Jakarta.

Riyadi, Slamet. 2000. Motivasi dan Pelimpahan Wewenang Sebagai Variabel Moderating dalam Hubungan Antara Partisipasi Penyusunan Anggaran dan Kinerja Manajerial. Jurnal Riset Akuntansi Indonesia. Vol.3, No.2, Hal. $134-150$.

Shields, M., and Young, M. 1998. Managing Innovation Costs: A Study of Cost Conscious Behavior by R\&D Professionals. Journal of Management Accounting Research. Vol.6, hal. 175-196.

Simamora, Henry. 1999. Manajemen Sumber Daya Manusia. Yogyakarta: STIE YKPN.

Sulistio, Eko Budi. 2010. Proses Penyusunan Anggaran Berbasis Kinerja (Studi pada Pemerintah Kabupaten Way Kanan. Jurnal Ilmiah Administrasi Publik dan Pembangunan. Vol.1, No.1.

Suwarno., Kamaliah., dan Zulbahridar. 2013. Pengaruh Partisipasi dalam Penyusunan Anggaran Terhadap Kinerja Manajerial dengan Motivasi, Pelimpahan Wewenang dan Pengetahuan Manajemen Biaya Sebagai Moderating. Jurnal SOROT. Vol. 8, No.2.

Wentzel, Kristin. 2002. The Influence of Fairness Perceptions and Goal Commitment to Managers Performance in Budget Setting. Behavioral Research in Accounting. Vol. 14. 